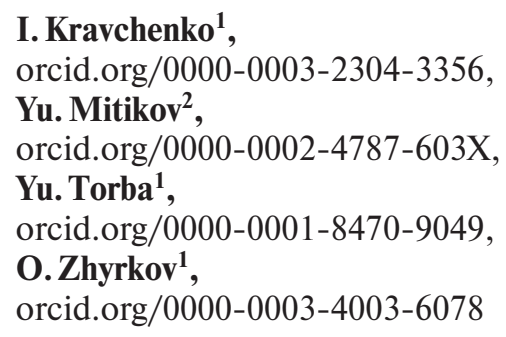

1 - Zaporizhzhia Machine-Building Design Bureau "Progress" State Enterprise named after Academician O. H. Ivchenko, Zaporizhzhia, Ukraine

2 - Oles Honchar Dnipro National University, Dnipro, Ukraine, e-mail: mitikov2017@gmail.com

\title{
NEW APPROACH TO INJECTION OF PRESSURIZING GAS INTO FUEL TANKS OF POWER UNITS
}

Purpose. Determination a rational way to injection of high-temperature pressurizing gas into fuel tanks of large elongation. Determination of longitudinal overload effect on the Archimedes force during the gas jet penetration in the tank. Reducing the need for pressurizing gas, the mass of the storage system.

Methodology. A retrospective design analysis of devices for injecting the gas into tanks and taxonomy basics are used. With their help, it is possible to determine the causes of a wide variety of device designs for injecting gas into tanks and the common fundamental disadvantages of all known devices.

Findings. As a result of the research carried out, a new method for supplying hot gas to the tanks has been found and substantiated. It is suitable for most conditions and provides a reduction in the need for pressurizing gas, does not reduce the operating fuel reserves, shows the trends for further research.

Originality. The main reason for the differences between the results of ground tests and flight tests in terms of the gas parameters in the tank and the temperature of its upper bottom has been determined. This is overload effect on the increase in the buoyancy force on hot pressurizing gas jet, which is injected traditionally - from the upper tank bottom to the side of the lower tank bottom. In this case, the buoyancy force acts against the dynamic component, reduces the jet range and presses the hot gas to the upper bottom. A new method for injecting the hot pressurizing gas, devoid of the indicated drawback, has been proposed and developed by using a theory of similarity. This makes it possible to mix the gas in the free volume of the tank as much as possible due to the action of the Archimedes force, to equalize gas temperature, reducing the maximum temperature at the upper bottom, and noticeable mass transfer processes in the tank are excluded.

Practical value. The application of the proposed method permits defining correctly and accurately the gas flow rate for tank pressurization, using it with a temperature of up to $\sim 1800 \mathrm{~K}$. The drop in gas pressure disappears in the tank at the initial moment of operation of the pressurization system, caused by the injection of a hot gas jet into the fuel surface. Depending on the conditions, the pressurizing gas requirement can be reduced by up to $50 \%$. In this case, the main fuel reserves in the tank are not reduced.

Keywords: propulsive unit, fuel tanks, high-temperature gas, inlet section, upper tank bottom

Introduction. Purpose of pressurization systems. At present, in various fields of technology, a method for squeezing out the liquid phase (water, fuel, chemicals, and so on) with compressed gas (generator gas) into centrifugal or other types of pumps is widely used. As an example, one can cite the oil and gas industry, aviation, firefighting, submarine fleet, missiles, chemical fields of industry, and others. Despite the external differences, these methods have a lot in common. By the way, the centrifugal pumps for the first V-2 ballistic missile for Werner von Braun were designed by a fire engineering design bureau. Therefore, the problem of optimizing the conditions for displacing the liquid phase from containers, finding new effective solutions, is very relevant for many fields of technology.

The present study relates to the field of missile and space technology, and more specifically to the systems of pressurization (PS) for fuel tanks of power unit (PU) of launch vehicles (LV). PSs are included in the composition of pneumohydraulic systems of fuel supply (PHSS) to the PU. They are the most complex and knowledge intensive part of the PHSS [1].

With a pumping system for supplying fuel components, PSs serve to develop such a level of gas pressure in the tanks, which provides:

- a stall-free mode (pseudo-cavitation mode) of centrifugal pump operation;

- a cavitation-free operation of the tank intake;

- a stability of thin-walled tanks in the active segment of the LV flight path. With multiple use of the stage the PS must guarantee the required gas pressure in the tank and in the section of its return.

(C) Kravchenko I., Mitikov Yu., Torba Yu., Zhyrkov O., 2021
The total required gas pressure in the tank in terms of the stage operation time in this case is the envelope of all three of the above requirements.

To ensure stall-free operation of the centrifugal pump, the required gas pressure in the tank $P_{t}$ should be, according to the publications of N. Belyaev and G. Usova, no less

$$
P_{t} \geq P_{\text {inlet }}-h \rho n_{x} g+\Delta P_{h l},
$$

where $P_{\text {inlet }}=P_{s}\left(t_{\text {inlet }}\right)+\Delta P_{a c m}$ is a required pressure of the fuel component at the pump inlet for its stall-free operation; $P_{s}\left(t_{\text {inlet }}\right)$ is a pressure of heavy vapors of the fuel component at its temperature at the pump inlet; $\Delta P_{a c m}$ is an anticavitation margin of the pump pressure; $h$ is a height of the column of the fuel component above the pump inlet; $\rho$ is a density of the fuel component; $n_{x}$ is a longitudinal overload; $g$ is an acceleration of gravity; $\Delta P_{h l}$ are hydraulic losses in the component pressure before penetrating into the pump.

The tank gas pressure required to ensure the cavitationfree operation of the intake device and for the stability of the tank is determined according to individual methods for specific designs.

With a positive displacement system for supplying fuel to the engine, the PSs serve to provide the required pressure in the combustion chamber. In this case, the required gas pressure in the tank is determined as follows

$$
P_{t}=P_{c c}+\Delta P_{h l}-h \rho n_{x} g,
$$

where $P_{c c}$ is pressure required in the engine combustio chamber.

The required gas amount in a free volume of the tank $V_{t}$ is determined by the well-known Clapeyron equation for an ideal gas 


$$
m=\frac{P_{t} V_{t}}{R T},
$$

where $V_{t}$ is a free volume of the tank; $R$ is a mass average gas constant of the working medium of pressurization in the tank; $T$ is a mass average temperature of the working medium of the pressurization in the free volume of the tank.

The main problems of designing pressurization systems. From (2) it follows that the required mass of the pressurized working medium in the tank is inversely proportional to its average mass temperature. The higher the mass average temperature of the gas in the tank is, the less pressurizing gas amount can be dispensed with, and the better the LV weight statement is. Therefore, the prevailing tendency in the design of PS is understandable to maximize the temperature of the working medium at the inlet to the tank, and, therefore, in the tank [2].

However, a higher gas temperature in the tank can result in negative consequences. These should include, first of all, increased evaporation of the fuel component (a decrease in its operating reserves). For example, Fig. 1 shows the rate of oxygen evaporation in the oxidizer tank of the first stage of the Zenit launch vehicle according to the engine operation time (data by Yu. Mitikov and S. Kubanov). During the first 20$30 \mathrm{~s}$ of flight, oxygen evaporation is mainly determined by the interaction of a hot helium jet with the oxidizer surface.

The next possible negative consequence is an increased heating of the upper fuel layer and, accordingly, an increase in the required gas pressure in the tank. This follows from the (1), since the pressure of saturated vapor of the liquid component $P_{s}\left(t_{\text {inlet }}\right)$ increases. Let us provide an example. An increase in the temperature of liquid oxygen by $1 \mathrm{~K}$ within the range of 85 to $98 \mathrm{~K}$ corresponds to an increase in its saturated vapor by $\sim 0.15 \mathrm{~atm}$. To ensure stall-free operation of the pumps, the gas pressure in the tank must also be raised by the same amount, which follows from (1). Moreover, this need arises at the end of the PU operation, when the upper layers of fuel penetrate into the engine. It is extremely difficult to increase the gas pressure in an almost empty tank. With gas-cylinder PS, the gas pressure in the cylinders at the end of the operation of the PU is minimal. With evaporative PS (generator), the component pressure at the tapping points is also minimal due to the throttling of the PU before cutoff. Therefore, in a number of cases, for these reasons, it is reached at the expense of high gas temperature in the tank.

The next negative consequence is the possible overheating of the upper bottom of the aluminum fuel tank, as a rule, integral one.

Literature review. To date, very few publications are known as related to the optimization of the conditions for the injection of non-isothermal working media into the free volumes of tanks. There are several explanations for this case. First, experimental studies on this type with simulation of at least some flight conditions (tank oscillations, external aerodynamic heating) are extremely unprofitable. They are comparable to testing the missile engines. Second, since 1965, tragic cases with silo-based Titan-II liquid-propellant intercontinental

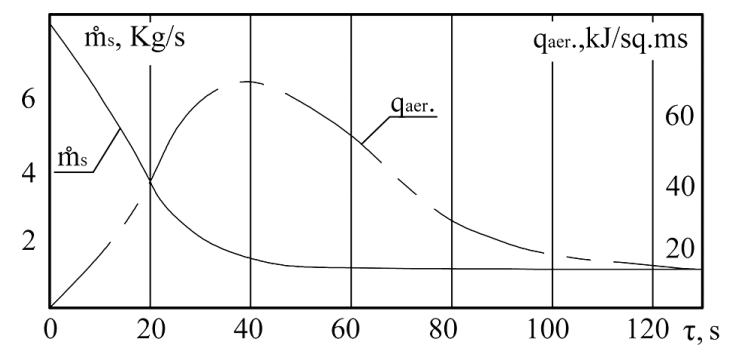

Fig. 1. Average supply of oxide vapor $m_{s}$ into a free volume of the tank of the first stage of $L V$ :

$q_{a e r}$ is a specific aerodynamic heat flux into the tank wall ballistic missiles (ICBMs) have occurred in the United States. Leaks of self-igniting fuel components, gas contamination, and other incidents caused dozens of casualties among service personnel. The evacuation of the population of nearby villages was carried out many times. In this regard, the US government decided to switch from liquid-propellant ICBMs to solid-propellant ones. The chemical industry accepted it. Funding in improving fuel supply systems for missile engines has ceased to be invested.

The situation was diametrically opposite in the Soviet Union. The constant upgrading of liquid-propellant ICBMs urgently required the improvement of fuel tank pressurization systems. This is how generator, mixed, chemical, high-temperature PSs appeared. Other PSs have also been investigated. It is not surprising that scientists and engineers of Ukraine and the Russian Federation have gone far ahead in these issues.

As for space missiles, they were not developed in the Soviet Union, including the Zenit launch vehicle (military index $11 \mathrm{~K} 77$ ) well-known later. ICBMs were modified for the conditions of launching various space objects. The famous Vostok, Voskhod and Soyuz-2 launch vehicles were initiated from the 8K71 ICBM and the upgraded 8K74.

In [3], general considerations, obtained in laboratory installations, on the use of gas inlets of various designs for cryogenic tanks are given. There are no specific recommendations, account of flight conditions, and the effect of the Archimedes number on the range capability of non-isothermal jets. In the study [4], the optimal helium injection rates for specific ground conditions are given for tanks of small elongation, the permanent temperature of helium at the inlet to the tank and its flow rate. For the latest helium gas cylinder PSs with heat exchangers, high throttled engines, the recommendations received are more informational in nature. Their main drawback is that they do not take into account the constraining effect of the tank design on the penetration of a non-isothermal jet and the influence of the flight factor of longitudinal overload, which significantly increases the buoyancy force on the jet of the pressurized working medium. In the study [5] carried out on liquid oxygen and hydrogen, the effect of external heat flows on the behavior of gas pressure in tanks, evaporation of cryogenic liquids at different pressures was studied. How and in what manner this pressure was generated, how long these important points were not considered. The article [6] examines the unique PSs of ICBMs developed in the Pivdenne design bureau. What gas inlets were used and with what PSs, how they were worked out, unfortunately, is not stated in the work.

Particular issues of helium use for pressurization have been considered in the technical (patent) literature. The process of gas pressure drop in a tank with oxidizer which takes place after its prelaunch pressurization with helium was researched in the article [7]. The article [8] is devoted to mathematical modeling of phase transitions in the system "cryogenic liquid free volume of a tank with helium". It is shown that the phase transition (boiling) has insignificant effect on the pressure in the tank. The research [9] considers different conditions of hot helium entering into the free volume of the tank. The conclusion was made that axial gas injection is more preferable than the "commonly" used radial injection. The failure factor of the system was determined (decrease in pressure in the tank).

All this gives grounds to assert that the search for optimal conditions for the injection of a high-temperature working medium of pressurization into the fuel tanks of current engines is an urgent task.

The method for injecting the gas into the tank means the speed, direction and shape of the jet of the pressurized working medium at the inlet to the free volume of the tank. A rational method of injection is understood as providing the required gas pressure in the tank with a minimum pressurizing gas flow rate with acceptable heating of the fuel and the upper bottom. In this case, experimentally, a compromise is sought to meet the conflicting requirements for the levels of gas pressure and 
temperature in the tank, and the heating of the boundary surfaces.

The implementation of the required method for injecting the working medium of the pressurization occurs through a special injecting device called a gas inlet. It is an actuating element of the PS, which mostly determines the nature of complex intra-tank processes in the active segment of the flight trajectory. It should be noted at a time that it is practically impossible to locate a gas inlet, designed in a due form of subsonic gas dynamics, in the initial free volume of the tank, which is about $1 \%$ of the total volume of the tank.

To better understand the requirements for the design of gas inlets, let us consider the conditions in which they have to operate.

A wide variety of gases are used as a working medium for pressurization:

- oxygen vapors (V2 rocket, the first stage of Saturn-V launch vehicle, RS-25 oxidizer tank, the second stage of Cosmos launch vehicle, two stages of P-9A ICBM, three stages of Н-1Л3 launch vehicle, and so on);

- nitrogen (two stages of Soyuz-2 launch vehicle, P-5A long-range ballistic missile (LRBM), fuel tank of the first stage of p-16 ICBM, tanks of Blue Streak LRBM, and others);

- air (V2 rocket fuel tank, oxidizer tanks of two stages of ICBM, two tanks of Redstone LRBM, fuel tank of P-12 LRBM, etc.);

generator gas, both oxidizing and reducing (ICBM of 8K67, 15A14, 15A15, 15A18, 15A18M, УP-100 (8K84), УP200 (8K81), УP-500 (Proton launch vehicle), and so on);

- decomposition products of hydrogen peroxide (oxidizer tank of the first stage of Cosmos launch vehicle);

- thermal decomposition products of asymmetrical dimetillhydrazine, (fuel tank of the second stage of Cosmos launch vehicle);

- Nitrogen tetroxide vapor (oxidizer tank of the first stage of Titan-2 ICBM); hicle);

- propane vapor (the second stage of Vanguard launch ve-

- helium (Viking, Atlas-D, Zenit, Falcon-9, Angara, Electron, Alfa launch vehicles, the first stage of Antares, Vulcan launch vehicles).

According to the temperature of the working medium at the inlet to the tank, the PS is classified as follows. Cold systems are systems in which the temperature of the pressurized working medium at the inlet to the tank approximately corresponds to the temperature of the component in the tank (the terminology by N. Belyaev). It is customary to call hot systems, in which the temperature of the pressurized working medium is by $300-450$ degrees higher than the component temperature. High-temperature systems are the systems with a temperature at the inlet to the tank up to $\sim 1300 \mathrm{~K}$ (fuel tank of the second stage of 15A18M ICBM, better known as Satana). PSs of tanks with RG-1 (RP-1) have been developed, using a generator gas with temperatures up to $1770 \mathrm{~K}$ (superhot) and similar for tanks with asymmetric dimethylhydrazine.

At present, hot helium PSs are most widespread in the world [1]. They are well studied; technologies for working with helium at all stages have been developed. Designing helium PSs does not require highly qualified designers. This may give the impression of their special reliability. But this is far from the case. Over the past ten years, there have been far more accidents due to the "fault" of helium systems than from failures of disproportionately more complex missile engines. Only with the famous Falcon-9 launch vehicle there were three such catastrophic accidents. At the same time, it is known that helium pneumohydraulic systems of fuel supply (PHSS) are also the most expensive parts of LVs after their engines [1].

Ultracold PSs are also known, which use helium at the inlet to the fuel tank with a temperature lower than the fuel in the tank by $\sim 180-200$ degrees. They are implemented for pressurizing tanks with RG-1 of two stages of Zenit LV of all variants, fuel tanks of the first stages of Energia LV, tanks with RP-1 of the first stages of Atlas-III and Atlas-V LVs. An improved super-cold pressurization method is used in the fuel tank of Antares LV. In this case, the tank itself, weighing several tons, and fuel, weighing several tens of tons, serve as a heat exchanger for helium with a cryogenic temperature.

The designs of the LV tanks are also very diverse. The most widely used are cylindrical integral tanks, spherical suspended, as well as conical and toroidal ones. To reinforce thin-walled tanks, wafer wall structures (mechanical or chemical milling), stringers and frames, and power cones are used. Tanks are made of aluminum and steel alloys, by winding various materials. The elongation of the tank (the ratio of its height to diameter) ranges from 0.8 to 6.0. The operating time of the PS varies within wide limits, from 60 to $900 \mathrm{~s}$.

The major problem of rational injection is for the diesel fuel oxidizer tanks of the PU of the first stages of the launch vehicle, since they are the longest (the proportion of the fuel components $\mathrm{km}$ oxygen and kerosene is $\sim 2.5$ to 1 , and highly concentrated hydrogen peroxide and kerosene is up to 8).

It is not surprising that for such broad conditions of use of gas inlets with a lack of a general theory of their design, hundreds of various designs are well known. As an example, for the sixtieth anniversary of the Department of Engine Engineering of Oles Honchar Dnipro National University, according to the most conservative estimates, it was determined that only the lecturers of the department, its graduates and students have received more than 350 patents for the design of gas inlets and PSs.

Methods. In accordance with the conclusions of the taxonomy, the main criteria due to which the classification of gas inlet designs is carried out today is the direction of injection of the pressurizing gas into the tank $[3,4]$. In the absence of a general theory of gas inlets, the known considerations for their design are formally quite simple. They are reduced to the following. For tanks of small elongation and spherical ones, it is recommended to inject the pressurizing gas mainly along the radius of the tank (parallel to the free surface of the fuel). In this case, the pressurizing gas is used with a temperature at the inlet to the tank of up to $700 \mathrm{~K}$. The designs of this group are usually called radial. This injection of the working medium allows one to reduce heat losses in the upper layer of the fuel. And the low temperature of the pressurizing gas should not result in overheating the upper bottom of the tank.

In order to guarantee the required rate and direction of injection of the pressurizing working medium, rather complex designs are required. One of such devices is shown in Fig. 2 (developed by V. Protopopov). It was a honeycomb device attached by use of resistance welding to three outer torus segments, each with a section of the inner torus. Torus segments are connected by supply lines. The outlet holes in the tori were $0.8 \mathrm{~mm}$ and burned with a laser. A special workshop was built for the production of such gas inlets. This gas inlet was used at the first stage of the N-1LZ launch vehicle of the Soviet Union's unrealized manned program to the Moon.

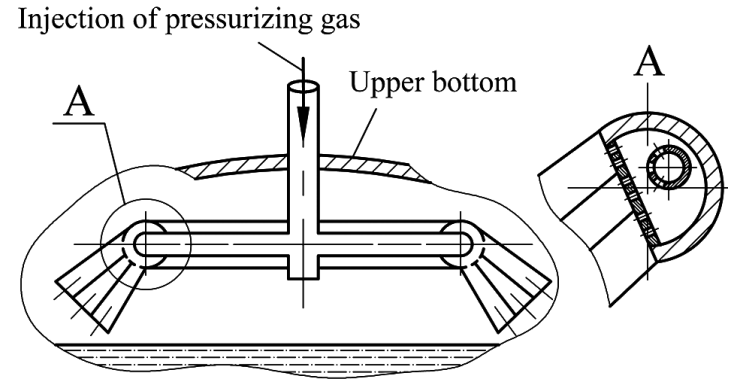

Fig. 2. Diagram of gas inlet for spherical oxidizer tank of $12.8 \mathrm{~m}$ in diameter of the first stage of $\mathrm{H}-1 Л 3 \mathrm{LV}$ 
For cylindrical tanks of large elongation, which are primarily characteristic of the oxidizer tanks of the first-stages, the recommendations are different. The high temperature gas should be injected along the longitudinal axis of the tank at a "reasonable" rate. Its value is determined experimentally. This allows hot gas to be withdrawn as the level is lowered into the depth of the tank, from the upper bottom. Mixing the gas in a large volume lowers the temperature of the gas at the top of the tank bottom. Designs of this type are usually known as axial ones.

It should be especially noted that most of the known designs were not blown down, particularly in the conditions close to natural ones. Therefore, for most of them, the recommendations made on the influence of the direction and rate of injection of the pressurizing gas are purely speculative. To illustrate the generalization made, Fig. 3 shows the designs of the original designs of gas inlets and modified ones [4]. Output velocity plots illustrate the meaning of the rework made. For example, in the design of the radial plate-type gas inlet II, the design velocity was planned at a level of $\sim 8 \mathrm{~m} / \mathrm{s}$ (with full filling of the outlet section). Blowing down showed a completely different pattern. Most of the outlet section in practice worked as an ejector. In the rest of the section, the gas injection rate was $\sim 34 \mathrm{~m} / \mathrm{s}$.

However, at the initial moment of the PS operation, when the exit of the axial gas inlet is in the immediate vicinity of the free surface of the fuel, a rather serious problem arises. In this case, the gas jet penetrates deeply into the fuel component. The pressurizing gas cools down. Vapors that are in the jet and injected into it are partially condensed. There is a sharp drop in the gas pressure in the tank. And, as you know, it is the start of the engine and the start of its operation that is the most crucial moment in the functioning of the entire missile complex. Most of the LV accidents occur at this particular time. Until now, the problem of the gas pressure drop in the tanks in the first seconds of the PS operation was solved by increasing the pressurizing gas flow rate. This increases the peripheral, not penetrating, part of the jet.

The so-called dual-mode (multi-mode) gas inlets are theoretically known (publications by V. Moseiko, A. Logvinenko). At the start of the PS operation, they should allow introducing the pressurizing gas along the radius of the tank, and then, over time, providing the supply of hot gas along the longitudinal axis of the tank. It would seem that this is a solution to the problems of a high-temperature gas injection. However, it has been shown theoretically that not all problems are solved in this case as well. Axial injection of helium even with a temperature of $\sim 550 \mathrm{~K}$ at any subsonic speed does not allow mixing the gas in the tank at a height of more than $\sim 1.5$ caliper (the ratio of the height to the diameter of the tank). The reason is the constraining effect of the tank design. The solution to this problem can be the multilevel designs, in which the outlet sections are located sequentially along the height of the tank (Yu. Mitikov). However, such designs have not been developed yet, and their switching time has not been determined. Also known is a method for injecting the hot pressurizing gas into

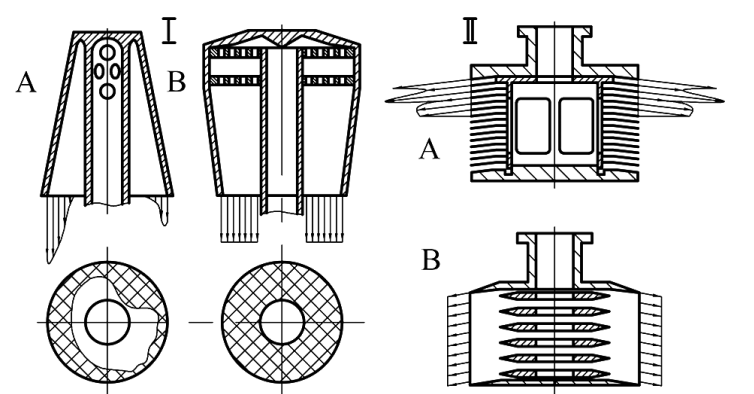

Fig. 3. Design and profiles of outlet velocities for original $(A)$ and reworked (B) axial (I) and radial (II) gas inlets [4] fuel tanks in the form of turbulent vortex rings (developed by N. Sviridenko, Yu. Mitikov). Its feature is a large gas mixing zone in the tank at a low injection rate (up to $\sim 10 \mathrm{~m} / \mathrm{s}$ ) and a supply frequency of $10-15 \mathrm{~Hz}$. With this method, it is possible to completely mix the gas in the free volume of the tank of any elongation (to equalize the gas temperature along the height of the tank) and not deform the free surface of the fuel in the tank. However, acceptable designs of vortex ring generators for pressurization systems have not been developed to date. This makes it impossible to use them in the current development of launch vehicles.

A critical analysis of all the considered methods for injecting a hot working medium of pressurization into the tanks indicates that they all have one fundamental drawback. It begins to appear itself with the start of flight tests. All designs, required costs, weight statements have already been determined by this stage of designing the missile complex. The hidden drawback under consideration is as follows. Clarification of the required gas flow rate for pressurization, its temperature at the inlet to the tank, the injection rate is carried out either with a full-scale tank, or with a simulated tank, but necessarily under the ground conditions. However, flight conditions differ from the ground conditions for the overload occurred. This results in the following negative consequences.

A longitudinal overload available should change and changes the pattern of the penetration of a non-isothermal jet in the tank as compared to the ground conditions. The range capability of the jet decreases, the hot gas is "pressed" against the upper bottom. The value of the drop in gas pressure in the tank at the start of the system operation is reduced. The gas pressure in the tank rises rather quickly and reaches the setting of the safety valve. The valve releases excess gas from the tank, as a rule, before the end of the start-up. There is a loss of energy. This is the price for the simplest design of a high-temperature PS.

The calculation of the parameters of turbulent jets with a high degree of non-isothermality is currently difficult even for the simplest cases. We will use a simple and repeatedly tested dependence for a weakly non-isothermal gas obtained by M. Grimitlin. Consider the equation describing the variation in the axial gas velocity along the length of an axisymmetric jet

$$
v_{x}=v_{o} m \frac{\sqrt{F_{o}}}{n} k_{n},
$$

where $v_{o}, F_{o}$ is a gas velocity and area in outlet section of gas inlet; $m, n$ are dimensionless shape factors of the injection device; $k_{n}=\sqrt{1 \pm 1.3 \cdot A r_{x}}$ is a non-isothermal factor; $A r_{x}=\frac{g n_{x} x \Delta t_{x}}{v_{x}^{2} T_{a m b}}-$ is an Archimedes test; $T_{a m b}$ is a gas temperature in the tank out of jet; $n_{x}$ is a longitudinal overload; $\Delta t_{x}$ is a gas temperature difference along the jet axis and in the free volume of the tank; $x$ is a distance from outlet section of gas inlet; $g$ is an acceleration of gravity.

The minus in (3) for $k_{n}$ is taken in the case of a mismatch between the direction of gas injection and the Archimedes force. This takes place in the case of the usual method of injecting the working medium of the pressurization from the upper bottom towards the lower one.

The $n_{x}$ - overload occurring during flight tests increases significantly the buoyancy force (Archimedes force) acting on the hot jet in the tank. The non-isothermal factor $k_{n}$ decreases. The gas velocity along the jet axis decreases. The gas jet interacts more weakly with the free surface of the fuel. A lower amount of the component evaporates. The jet penetrates to a smaller distance in the tank; it is pressed against the upper bottom. The parameters of the gas in the tank vary in comparison with those obtained on the ground. The higher the temperature of the pressurized working medium injected into the free volume of the tank is (the greater the density difference), the greater the difference between the ground and flight results is. 
Under the ground conditions, an increased drop in gas pressure in the tank is implemented at the start of the PS operation. A simple way out of this situation was found and consisted in increasing the gas flow rate for pressurization. When using generator gas with a temperature of $\sim 1300 \mathrm{~K}$ in the fuel tank of the 15A18M ICBM during flight tests, almost unfavorable results were obtained for the temperature of the relief valve design. The increased generator gas flow rate, taken as a result of ground tests, resulted in increase of gas pressure in the tank, an increase in the density of heat fluxes into the boundary surfaces. The problem had to be solved.

In the publication by $\mathrm{Yu}$. Mitikov, it is proposed to take into account the flight overload available during the development of the PS in the ground conditions as follows

$$
T_{a m b . g}=T_{o}-\left(T_{o}-T_{a m b . f}\right) \cdot \frac{T_{a m b . g}}{T_{a m b . f}} \cdot n_{x},
$$

where $g$ is subscript means on the ground; $f$ is subscript means in flight.

To obtain the same parameters of the gas in the tank (temperature, pressure) on the ground as in flight, it is necessary to reduce the average mass temperature of the gas in the tank at the initial moment of time, or to increase the temperature of the working medium at the inlet to the tank. But the indicated temperatures should be related to each other according to the dependence (4). In this case, the magnitude of the Archimedes force on the ground will correspond to the flight magnitude. It is interesting to note that the obtained relationship of physical parameters, resulted in a positive result, has been patented. But at the same time, it is known that physical simulation of complex thermal processes is approximate, it implies the need for reserves and is not considered as a radical solution to the problem.

Let us put a question: What gives rise to the problem of using a high-temperature gas to pressurize a thin-walled tank? The answer is simple: either intensive interaction of the jet with the fuel surface at the initial moment of the PS operation and a pressure drop, or overheating of the upper bottom of the tank.

Let us attempt to answer the question: Is it possible to avoid these negative phenomena and, if possible, in what way?

A retrospective analysis of the known designs of gas inlets shows that they all have one common feature. It is this feature that gives rise to the problem. They inject hot pressurizing gas from the top of the tank to the bottom of it. In this case, the jet of lower density overcomes the buoyancy force (the Archimedes force) of the medium of higher density. This is what results in differences in parameters during the ground and flight testing, when the Archimedes force increases significantly. The patent [10] proposes a fundamentally new approach to the injection of hot pressurizing gas into the fuel tanks of the power unit. The problem disappears if the high-temperature pressurizing gas is injected during the operation of the power unit from the fuel level towards the upper bottom of the tank. As can be seen from expression (3), due to an increase in the non-isothermal factor $k_{n}$, the velocity along the jet axis will decrease more slowly, while increasing the gas mixing zone in the tank.

The proposed method can be implemented as follows. At the start of the PS operation, the high-temperature working medium of the pressurization is injected into the free volume of the tank in the direction of the upper bottom from the fuel surface, for example, from the float. This solution radically protects the top layer of the fuel from the hot pressurizing jet impacting it. This means that the drop of the gas pressure at the start of the PS operation is also excluded. Part of the upper bottom, opposite to the outlet section of the device, can be protected by a thin-walled steel shield or covered with ceramic heat insulation of several tens of microns thick.

It should be emphasized that the introduction of the working medium of pressurization in the direction of the upper bot- tom can be carried out at an acute angle to the longitudinal axis of the tank. This lengthens the path of the jet, reduces its velocity of contact with the upper bottom. Due to the oscillation of the free surface of the fuel in flight, the direction of the injection of the jet of the working medium of the pressurization from the float will also change somewhat. This eliminates the local effect of the jet at one point on the upper bottom of the tank and increases the mixing of the gas in the tank (reduces the temperature of the gas at the upper bottom of the tank).

Elastic heat-resistant materials, such as Kevlar, can be used to supply the hot gas to the injection point. To increase the mixing zone (using the hottest working medium of pressurization), the following operation should be performed. When the range capability of the working medium of pressurization jet becomes less than the distance from the fuel surface to the upper bottom, you can fix the gas injection level and pause. In this case, the working medium of pressurization continues to be injected towards the upper bottom. When the fuel level drops to a safe distance, equal, for example, to the range capability of the jet against the Archimedes forces, the injection of the hot working medium of pressurization is provided in the direction of the lower bottom of the tank. This can be done using a switch valve. The above techniques show the possibility of implementing the proposed method with using the existing technical means.

It should be especially noted that the proposed method provides a large gas mixing zone in the tank in flight conditions compared to the ground testing. This allows one to have a margin of gas pressure in the tank due to a lower heat flow in its upper bottom, and, therefore, a higher average mass temperature of gas in the free volume of the tank. After several flight tests, it is possible to adjust safely the pressurizing gas flow rate decreasingly.

Calculations of the efficiency of the proposed method show the possibility of using helium for pressurizing tanks with oxygen with a temperature at the inlet to the tank of $\sim 1800 \mathrm{~K}$. In this case, the required mass of the pressurizing gas decreases by $\sim 50 \%$, with all other conditions being equal. For example, for the first stage of the Energia launch vehicle, this is equivalent to removing nine 132-liter titanium cylinders with helium.

Conclusions. The analysis of the operating conditions of the devices for injecting the working medium of the pressurization into the tanks shows their great variety. It concerns both the gases used and their temperature, and the design of fuel tanks, their materials and reinforcements, and the operating time. One of the main trends in the design of PS is a consistent increase in the temperature of the working medium of the pressurization at the inlet to the tank. This significantly improves the characteristics of the systems for supplying fuel components to the engine. By now, the temperature of $1300 \mathrm{~K}$ of the generator gas of the pressurization of the aluminum tank has been implemented. The use of working media with an even higher temperature (up to $1800 \mathrm{~K}$ ) has been investigated.

A unified theory of design of gas inlets has not been developed yet. The known recommendations for their development are rather arbitrary in nature due to the lack of a detailed study on designs in real conditions (blow downs). This can explain a vast number of different gas inlets.

The major problem of designing rational designs of gas inlets for high-temperature PSs relates to tanks of large elongation (oxidizer tanks of the first stage). All known designs of gas inlets, with all their diversity, have one feature in common: they inject the pressurizing gas from the upper bottom to the side of the fuel surface. This is what gives rise to the following main problem. The acceptable gas flow rate for pressurization, its temperature, and injection rate, selected in this case according to the results of ground tests of the PS, provide noticeably different results during flight tests (the nature of the variation in the gas pressure in the tank according to the operating 
time of the power unit, the temperature of the upper bottom of the tank). This is explained by a significant increase in the buoyancy force (Archimedes force) due to the overload occurred. In this case, the buoyancy force acts against the dynamic component, reduces the jet range capability and presses the gas against the upper bottom.

A new injection method, devoid of the indicated drawback, is proposed and described. It is recommended to inject the high-temperature working medium of the pressurization from the fuel level in the direction of the upper bottom. This makes it possible to mix the gas as much as possible in the free volume of the tank due to the enhancing action of the Archimedes force, to equalize its temperature, while reducing its maximum value at the upper bottom. The mass-exchanging processes in the tank are reduced to a minimum; the working fuel reserves are not reduced. With this method of injection, the differences between the results of flight tests and ground tests will be for the better. The drop in gas pressure in the tank at the initial moment of the PS operation, caused by the introduction of a hot gas jet into the fuel surface, disappears. To protect the upper bottom from a jet of hot gas at start of the PS operation, it is proposed to use existing heat-insulating materials with a thickness of several tens of microns.

\section{References.}

1. Degtyarev, A. V., Kushnarev, A. P., \& Popov, D. A. (2014). Ultrasmall space rocket/Space technology. Missile armament: Sat. scientific and technical Art. GKB "Yuzhnoye", 1, 14-20.

2. Mitikov, Yu.A., Antonov, V.A., Voloshin, M.L., \& Logvinenko, A. I. (2012). Ways to improve the reliability and safety of missile systems operation. Aviation and Space Engineering and Technology, 3(90), 30-36

3. Hermsen, R. J. G. (2017). Cryogenic propellant tank pressurization. Practical investigation on the collapse factor for small, high-pressure, cryogenic rocket propellant tanks, 161.

4. Denisov, K. P. (2015). On the issue of working out the systems of pressurization and displacement of high-boiling and cryogenic fuel components from the tanks of the LV stages of heavy and super-heavy classes. Rocket engines and power plants. Materials of anniversary reports, 56-61.

5. Sumith, S., \& Ramesh Kumar, R. (2021). Thermo-structural analysis of cryogenic tanks with common bulkhead configuration. Proceedings of the Institution of Mechanical Engineers, Part G: Journal of Aerospace Engineering. https://doi.org/10.1177/09544100211024789. 6. Voloshin, M. L., Kuda, S.A., Logvinenko, A.I., Mashchenko, A. N., \& Shevtsov, E. I. (2019). Experience in the development and application of generator systems for pressurizing the tanks of launch vehicles using high-boiling components. Space Technology. Missile Armaments, 1(117), 45-53. https://doi.org/10.33136/stma2019.01.045.

7. Kim, K. H., Ko, H. J., Kim, K., Jung, Y. S., Oh, S. H., \& Cho, K. J. (2012). Transient thermal analysis of a cryogenic oxidizer tank in the liquid rocket propulsion system during the prelaunch helium gas pressurization. Journal of Engineering Thermophysics, 21(1), 1-15.

8. Wang, L., Li, Y., Li, C., \& Zhao, Z. (2013). CFD investigation of thermal and pressurization performance in LH2 tank during discharge. Cryogenics, 57, 63-73.

9. Hermsen, B., \& Zandbergen, B. (2017). Pressurization system for a cryogenic propellant tank in a pressure-fed high-altitude rocket. $7^{\text {th }}$ European conference for aeronautics and aerospace sciences (eucass). https://doi.org/0.13009/EUCASS2017-220.

10. Mitikov, Yu. A., \& Koryachko, K.V. (2021). The method of inflating the fuel tank of the propulsion system with hot gas (Ukraine Patent No. 123831).

\section{Новий підхід до введення газу наддування в паливні баки рушійних установок}

\author{
І. Ф. Кравченко ${ }^{1}$, Ю.А. Мітіков ${ }^{2}$, Ю. І. Торба ${ }^{1}$, \\ О.Г. Жирков ${ }^{1}$
}

1 - Державне підприємство Запорізьке машинобудівне конструкторське бюро «Прогрес» імені академіка О. Г. Івченка, м. Запоріжжя, Україна

2 - Дніпровський державний університет імені Олеся Гончара, м. Дніпро, Україна, e-mail: mitikov2017@gmail.com

Мета. Знаходження раціонального методу введення високотемпературного газу наддуву в паливні баки великого подовження. Визначення впливу поздовжнього перевантаження на сили Архімеда при поширенні струменя газу в баку. Зниження потреби в газі наддуву, маси системи його зберігання.

Методика. Використано ретроспективний аналіз конструкцій пристроїв уведення газу в баки та основи таксономії. 3 їх допомогою визначені причини великої різноманітності конструкцій пристроїв уведення газу в баки та загальні корінні недоліки всіх відомих пристроїв.

Результати. У результаті проведених досліджень знайдено та обгрунтовано новий спосіб подачі гарячого газу в баки. Він підходить для більшості умов і забезпечує зниження потреби в газі наддування, не знижує робочі запаси палива, показує напрям подальших досліджень.

Наукова новизна. Визначена основна причина відмінностей результатів наземних випробувань від льотних за параметрами газу в баку, по температурі його верхнього днища. Це вплив перевантаження на збільшення сили, що виштовхує струмінь гарячого газу наддування, який вводять традиційно - від верхнього днища бака в сторону нижнього. У цьому випадку виштовхувальна сила діє проти динамічної складової, зменшує далекобійність струменя й підтискає гарячий газ до верхнього днища. Із використанням теорії подібності запропоновано й розроблено новий спосіб уведення гарячого газу наддування, що позбавлений зазначеного недоліку. Це дозволяе максимально перемішувати газ у вільному обсязі бака завдяки дії сили Архімеда, вирівнювати його температуру, знижуючи іiі максимум у верхнього днища, а також виключаються помітні масообміні процеси в баку.

Практична значимість. Застосування запропонованого способу дозволяє правильно й точно призначити витрати газу на наддування баку, використовувати його за температури до $\sim 1800 \mathrm{~K}$. Зникає провал тиску газу в баку в початковий момент роботи системи наддуву, викликаний упровадженням гарячого струменя газу в поверхню палива. Потреби в газі наддуву можна скоротити в залежності від умов до $50 \%$. У цьому випадку не зменшуються робочі запаси палива в баку.

Ключові слова: рушійні установки, паливні баки, високотемпературний газ, вхідний пристрій, верхнє днище бака

The manuscript was submitted 07.04.21. 